\title{
Glucocorticoid-Induced Leucine Zipper (GILZ) in Cardiovascular Health and Disease
}

\author{
Donato Cappetta ${ }^{1}$, Oxana Bereshchenko ${ }^{2}$, Eleonora Cianflone ${ }^{3}$, Francesco Rossi ${ }^{1}$, Carlo Riccardi ${ }^{4}$, \\ Daniele Torella ${ }^{5}$, Liberato Berrino ${ }^{1}$, Konrad Urbanek ${ }^{5}$, Antonella De Angelis ${ }^{1, *}$ and Stefano Bruscoli 4
}

\section{check for} updates

Citation: Cappetta, D.; Bereshchenko, O.; Cianflone, E.; Rossi, F.; Riccardi,

C.; Torella, D.; Berrino, L.; Urbanek,

K.; De Angelis, A.; Bruscoli, S.

Glucocorticoid-Induced Leucine

Zipper (GILZ) in Cardiovascular Health and Disease. Cells 2021, 10, 2155. https://doi.org/10.3390/ cells10082155

Academic Editor: Pablo García De Frutos

Received: 13 July 2021

Accepted: 16 August 2021

Published: 21 August 2021

Publisher's Note: MDPI stays neutral with regard to jurisdictional claims in published maps and institutional affiliations.

Copyright: (c) 2021 by the authors. Licensee MDPI, Basel, Switzerland. This article is an open access article distributed under the terms and conditions of the Creative Commons Attribution (CC BY) license (https:/ / creativecommons.org/licenses/by/ $4.0 /)$.
1 Department of Experimental Medicine, University of Campania 'Luigi Vanvitelli', 80138 Naples, Italy; donato.cappetta@unicampania.it (D.C.); francesco.rossi@unicampania.it (F.R.); liberato.berrino@unicampania.it (L.B.)

2 Department of Philosophy, Social Sciences and Education, University of Perugia, 06123 Perugia, Italy; oxana.bereshchenko@unipg.it

3 Department of Medical and Surgical Sciences, University 'Magna Graecia' of Catanzaro, 88100 Catanzaro, Italy; cianflone@unicz.it

4 Department of Medicine and Surgery, Section of Pharmacology, University of Perugia, 06156 Perugia, Italy; carlo.riccardi@unipg.it (C.R.); stefano.bruscoli@unipg.it (S.B.)

5 Department of Experimental and Clinical Medicine, University 'Magna Graecia' of Catanzaro, 88100 Catanzaro, Italy; dtorella@unicz.it (D.T.); urbanek@unicz.it (K.U.)

* Correspondence: antonella.deangelis@unicampania.it

Abstract: Glucocorticoids (GCs) are essential in regulating functions and homeostasis in many biological systems and are extensively used to treat a variety of conditions associated with immune/inflammatory processes. GCs are among the most powerful drugs for the treatment of autoimmune and inflammatory diseases, but their long-term usage is limited by severe adverse effects. For this reason, to envision new therapies devoid of typical GC side effects, research has focused on expanding the knowledge of cellular and molecular effects of GCs. GC-induced leucine zipper (GILZ) is a GC-target protein shown to mediate several actions of GCs, including inhibition of the NF- $\mathrm{KB}$ and MAPK pathways. GILZ expression is not restricted to immune cells, and it has been shown to play a regulatory role in many organs and tissues, including the cardiovascular system. Research on the role of GILZ on endothelial cells has demonstrated its ability to modulate the inflammatory cascade, resulting in a downregulation of cytokines, chemokines, and cellular adhesion molecules. GILZ also has the capacity to protect myocardial cells, as its deletion makes the heart, after a deleterious stimulus, more susceptible to apoptosis, immune cell infiltration, hypertrophy, and impaired function. Despite these advances, we have only just begun to appreciate the relevance of GILZ in cardiovascular homeostasis and dysfunction. This review summarizes the current understanding of the role of GILZ in modulating biological processes relevant to cardiovascular biology.

Keywords: glucocorticoid-induced leucine zipper; glucocorticoids; cardiovascular disease; inflammation

\section{Introduction}

Stress is a well-recognized factor in cardiovascular diseases [1]. According to the first definition of stress by Hans Selye in 1936 as "the non-specific neuroendocrine response of the body" [2], all stimuli are "stressors" that produce a general response regardless of the stressors' nature, resulting in the unbalanced homeostasis of the organism [3]. In recent decades, a myriad of studies have confirmed the role of biological stress (oxidative, hemodynamic, metabolic, etc.) in cardiovascular disease, and have linked cardiovascular risk factors to chronic stress. Furthermore, mental and emotional stress may determine the course towards cardiovascular disease [4].

Chronic exposure to stressors causes endocrine and immune dysregulation that sustains low-grade inflammation, which evolves to become systemic and detrimental. The endocrine system responses to stress by producing and secreting hormones that regulate a 
wide range of biological functions, including growth and development, sexual reproduction, metabolism, heart rate, blood pressure, sleeping and waking cycles, etc. [5,6]. GCs are also called "stress hormones", and their increased secretion upon anxiety and severe injury is desirable, but when chronically elevated, circulating GCs are linked to adverse cardiovascular outcomes $[7,8]$. The role of GCs in maturation of the fetal heart further supports the importance of GC signaling in cardiovascular biology $[9,10]$.

The purpose of this review is to outline the possible role of GC-induced leucine zipper (GILZ) in the cardiovascular system, accentuating its contribution to the adaptations of stressed myocardium and the vascular response upon chronic stress. Although the available data are limited at present, the role of this GC-target protein possibly extends beyond its anti-inflammatory/immunosuppressive effects.

Herein, a section that highlights GC signaling and its role in the cardiovascular system was kept synthetic as these arguments are extensively reviewed elsewhere [6,11].

\section{Glucocorticoid Signaling}

GCs are a highly conserved family of steroid hormones released upon the activation of the hypothalamic-pituitary-adrenal axis. In response to stress, cortisol is secreted by adrenal glands into the bloodstream, through which it reaches tissues and organs where it coordinates physiological processes such as energy metabolism, resolution of inflammation, sperm maturation, and endocrine functions [6,12-14].

Physiological and pharmacological actions of endogenous and exogenous GCs are mediated by the GC receptor (GR), a member of the nuclear receptor superfamily of transcription factors, which in its inactive state is confined within the cytoplasm, bound to heat shock proteins and immunophilins (including hsp90, hsp70, FKBP52) [15]. The genomic mechanisms of transcriptional control operate in the nucleus. After binding, the ligand-receptor complex translocates to the nucleus in its dimeric form where it binds to specific DNA sequences, known as GC response elements, activating or suppressing gene transcription, thus mediating most of the GC effects. Increased gene transcription is mostly determined by homodimerization of the activated GR and its binding to DNA regulatory regions called GC-responsive elements (GREs), while decreased gene transcription results from heterodimerization of activated GR with other transcription factors, thus inhibiting their transcriptional activity. Another important mechanism by which GCs indirectly decrease gene transcription is the upregulation of inhibitors of transcription factors or the interaction with negative GREs [16]. Non-genomic effects are mainly characterized by a short delay of action and often involve modulation of intracellular signal-transduction cascades, such as phospholipases, cyclic AMP, protein kinases and calcium mobilization [17]. Actinomycin-D or cycloheximide, which are inhibitors of protein synthesis, did not revert the non-genomic effects, thus suggesting that these effects of GCs do not involve protein synthesis and hence are very rapid. These effects require GC/GR interaction, suggesting that GR most liley has other functions apart from its classic role as transcription factor. These rapid GC effects may also affect the cardiovascular system; for example, GR activation has been linked to rapid biological reduction in contractility, vascular reactivity, and endothelial nitric oxide synthase (eNOS) activation [18]. On the other hand, GR may interact with many kinases or transcription factors in the cytosolic compartment (i.e., nuclear factor- $\mathrm{KB}$ (NF- $\mathrm{kB}$ ) or PI3K-Akt), so that direct and indirect transcription regulation is consequent to GC treatment [19-22].

The GR consists of various portions: in the $\mathrm{N}$-terminal end is present the transactivation domain; the central section of the polypeptide chain is highly conserved (containing zinc fingers motifs necessary to bind DNA), while the $C$-terminal portion allows binding of the ligand. In humans, the gene for GR is located on the long arm of chromosome 5, is composed of 9 exons and, since exon 9 can be incorporated into the transcript in an alternative way, it serves as a template for at least two mRNAs: GR- $\alpha$ and GR- $\beta$. GR- $\alpha$ consists of 777 amino acids, is ubiquitous, regulates the expression of thousands of genes, and is necessary for life. In GR- $\beta$, on the other hand, the hormone-binding region is so 
short that it does not allow binding to the GC; it is localized in the nucleus, it is inactive, and it functions as a dominant negative. The different isoforms are then translated from multiple translation start sites, and undergo various post-translational modifications, which generate an additional level of complexity of GR biology [12,15].

\section{GILZ in the Immune System}

GILZ was first reported as a gene induced by synthetic GC dexamethasone and was found in murine lymphocytes from the thymus, lymph nodes, and spleen [23]. A human homologue of murine GILZ protein was shown in circulating $\mathrm{T}$ cells and monocytes with $97 \%$ identity in amino acid sequence [24]. A large body of evidence demonstrates that GILZ is a GC-induced downstream effector, one of the earliest transcriptional targets of the activated GR. Hence, GILZ, by mediating the effects of GCs, has anti-inflammatory properties upon innate and adaptive immune cells [25]. GILZ controls essential transcription factors and cellular pathways involved in the inflammatory/immune process by physically interacting with NF- $\mathrm{KB}, \mathrm{c}-J u n / \mathrm{c}-F$ os heterodimer, Raf-1, and Ras, among others [26-30]. At the cellular level, GILZ mediates typical GCs effects such as regulation of thymocyte and lymphocyte survival, neutrophil migration, macrophage activation, dendritic cell maturation, and B-cell homeostasis [25,31-37]. As well as GCs, GILZ supports T-cell differentiation toward an anti-inflammatory phenotype through the inhibition of Thelper type-1 and type- 17 proliferation and the increasing response of $\mathrm{T}$ helper type- 2 and $\mathrm{T}$ regulatory cells [38-42].

Moreover, other members of the nuclear receptor superfamily, in addition to the GR, are involved in the modulation of immune response, inflammation and GILZ regulation. Activation of peroxisome proliferator-activator receptor alpha (PPAR- $\alpha$ ) leads to antiinflammatory effects due to the reduction in immune cell tissue infiltration and expression of pro-inflammatory cytokines, chemokines, and cell adhesion molecules [43,44]. Further, PPAR- $\alpha$ contributes to the transcriptional upregulation of GILZ mediated by GCs [45]. The renal mineralocorticoid receptor represents a third nuclear receptor involved in GILZ modulation. Evidence shows that GILZ is upregulated by aldosterone in the kidney [46]. Both GILZ and serum/GC regulated kinase 1 (the protein that participates in the control of inflammation) were among the five direct target genes of mineralocorticoid receptor activation $[47,48]$.

Similar to GR that is virtually expressed in all organs, GILZ expression is not restricted to lymphoid tissue. It has been implicated in the regulation of the inflammatory response in a variety of cells in the myocardium, skeletal muscle, brain, kidney, adipose tissue, testis, and pulmonary epithelium and endothelium [24,49-52].

\section{GCs in Cardiovascular Physiology and Diseases}

In mammals, a remarkable GC rise occurs late in gestational time, and it is essential for fetal maturation and the development of many organs in preparation for extra-uterine life [53]. Hence, GCs are routinely administered to women at risk of preterm birth to accelerate fetal maturation and improve neonatal outcome [54]. Although prenatal GC treatment has been reported to promote growth responses of cardiomyocytes and vascular structures [55,56], the direct effect on structural and functional maturation of the cardiovascular system remains scarcely understood. Some insight into the role of GC signaling in late-gestation cardiovascular maturation comes from in vivo studies conducted on GRknockout mice, in which structural and biochemical myocardial alterations with severe functional impairment were found $[57,58]$. Notably, both global and heart (cardiomyocytes and vascular smooth muscle cells) deficiency in GR produced similar abnormalities, including disorganized myofibrils and irregular cellular alignment. However, myocardial dysfunction, as far as diastolic performance is concerned, is more evident when GR disruption occurs at the whole-body level [57]. These data suggest that local GC signaling is essential to elicit physiological heart maturation. Additional evidence shows the importance of GC signaling in maintaining normal cardiovascular function in the young 
heart. Mice, in which GR was specifically deleted in cardiomyocytes, showed a reduction in systolic function and increased hypertrophy at the age of three months. Microarray analysis revealed dysregulated expression of genes associated with cardiomyocyte contractility, cardiac hypertrophy, and heart failure, such as dystrophin, ryanodine receptor 2, Kruppel-like factor 15, and the lipocalin-type prostaglandin D synthase. Ultimately, GR deficiency leads to premature death in both male and female mice [58]. Interestingly, using RNA sequencing it has been shown that GILZ is one of the primary targets of GR in fetal cardiomyocytes [59].

In addition to the contribution to heart maturation, GCs are also involved in the pathogenesis of cardiovascular diseases. Clinically, circulating GCs are an independent risk factor for cardiovascular diseases, and GC-dependent adverse effects such as diabetes, obesity, and hypertension impair the cardiovascular stress response [7,11,60-64]. Endocrine disorders with high and low levels of GCs involve cardiovascular complications. In the heart, GCs regulate a cluster of cardiomyocyte genes important for cell survival and function and for repressing the hypertrophic program $[58,65,66]$. GCs are also known to affect vascular remodeling by regulating a vast array of signaling pathways that include oxidative stress, vascular inflammation, and nitric oxide biosynthesis $[67,68]$. The inhibition of the expression of the vascular endothelial growth factor gene in vascular smooth muscle cells marks their capacity as anti-angiogenic agents $[69,70]$. Interestingly, the activation of GR in adult cardiomyocytes is required for the maintenance of the T-tubule system. The remodeling of these ultrastructures that are the extensions of cellular membrane that penetrate into the cell, permitting a rapid transmission of the action potential, is considered a potential target in heart failure [71]. GCs signaling seems crucial for T-tubule formation also in human-induced pluripotent stem cell-derived cardiomyocytes, and this can be relevant to the challenging issue of cell maturation that is one of the barriers for the cell therapy in the heart [72].

\section{GILZ in the Cardiovascular System}

\subsection{Chronic Inflammation}

The experimental and clinical studies that link the innate and adaptive immune systems to the pathogenesis of heart failure have grown exponentially since the original description in 1990, of the ongoing inflammatory response in patients with chronic heart failure. Pro-inflammatory cytokines (tumor necrosis factor alpha (TNF- $\alpha$ ), interleukin- $1 \beta$ (IL-1 $\beta)$, IL-6, IL-8, IL-17, and IL-18), detected in the heart of patients with heart failure (but not in non-failing hearts), can induce compensatory cardiac hypertrophy and fibrosis in the setting of cardiac injury [73-75]. The quantity of circulating cytokines positively correlates with adverse cardiovascular outcomes and prognosis [76]. On the other hand, a wide array of immune cells (monocytes, macrophages, T lymphocytes, B lymphocytes, and neutrophils) has been observed in the hearts from patients with heart failure in the absence of discernible myocardial injury or infection [49,51,73,77]. Increased recruitment of immune cells to failing myocardium contributes to adverse remodeling and myocardial dysfunction [10,78]. Macrophages, for instance, are centrally involved in inflammatory tissue remodeling, resolution of inflammation after myocardial infarction and left ventricular remodeling [79]. The function of macrophages in the heart is largely unknown, and we can hypothesize that GILZ expression in macrophages could affect their function in the steady state or in the genesis of heart failure. Indeed, it has been previously shown that downregulation of GILZ expression increases macrophage activation [80].

Chronic inflammation is one of the essential processes in the pathogenesis of heart failure, traditionally a "non-inflammatory" disease, and represents an independent cardiovascular risk factor [81]. While the importance of GC signaling and GILZ in triggering inflammatory cascade and sustaining low-grade chronic inflammation is compelling in the cardiovascular context, at least equally fascinating is the question of how GCs and GILZ impact non-inflammatory myocardial cells (cardiomyocytes, coronary vascular cells) in the pathological condition. The main pieces of research, discussed below, are listed in Table 1. 


\subsection{Vascular Dysfunction}

The activation and dysfunction of the endothelium in response to pathologic stimuli is a well-recognized component of the evolution of heart failure syndrome. The dynamic interface between microvasculature and immune cells relies on the upregulation of surface molecules to interact with leukocytes and platelets, in order to capture leukocytes from the bloodstream and trigger their extravasation and recruitment, thus targeting inflammation to specific tissues [82]. Another implication of the continuous release of pro-inflammatory cytokines is the development of endothelial dysfunction, linked to a deficit in eNOS function and nitric oxide bioavailability, hallmarks of hypertension, heart failure and chronic conditions with a prominent vascular component such as diabetes and aging $[83,84]$. Inflammatory activation of endothelial cells also plays a central role in the accumulation of inflammatory cells and lipids in the vascular wall during atherogenesis [85].

The role of GILZ in the vascular system has been investigated in several studies. The mechanism by which GILZ exerts an anti-inflammatory role in endothelial cells mainly involves NF- $\mathrm{kB}$, whose inhibition may occur through different mechanisms (phosphorylation status, nuclear translocation, or cytoplasmic sequestration), resulting in downregulation of cytokines, chemokines, and cellular adhesion molecules.

In a pioneering study, microarray screening of human umbilical vein endothelial cells (HUVECs) under shear stress evaluated groups of genes involved in cellular functions, such as cell proliferation and differentiation, maintenance of vascular tone, extracellular matrix organization, and inflammatory process. Among inflammation-regulating genes with significantly altered expression, the analysis revealed an enhanced expression of GILZ [86].

Other investigations conducted on human and rodent endothelial cells have followed this early report. In the first study on the role of GILZ in human endothelial cells, overexpression of GILZ via transient transfection was associated with decreased expression of pro-inflammatory molecules. After TNF- $\alpha$ treatment, the levels of IL- 6 , and IL-8, adhesion molecules E-selectin, and intercellular adhesion molecule 1 (ICAM-1], and chemokine monocyte chemoattractant protein 1 (MCP-1) were significantly lower in GILZ-overexpressing cells compared to non-transfected cells. Through the modulation of NF- $\mathrm{kB}$ p65 subunit-DNA binding, exogenous GILZ exerted inhibitory effects on endothelial cell adhesive function, reducing the capacity of HUVECs to support TNF $\alpha$-dependent leukocyte rolling, adhesion, and transmigration. In contrast, silencing endogenous GILZ in GC-treated and -untreated HUVECs did not alter their TNF $\alpha$-induced adhesive function. The findings also indicated that the suppression of NF- $\mathrm{KB}$ transcriptional activity did not entirely depend on a protein-protein interaction that prevents $\mathrm{p} 65$ nuclear translocation. The experiments conducted in HUVECs were then performed in human microvascular endothelial cells as well; the analyses showed comparable findings with GILZ having the same impact on NF-kB-dependent transcriptional activity in human microvascular endothelial cells, which respond to GILZ in a manner consistent with the response in primary HUVECs. These results revealed a previously unrecognized potential of GILZ to inhibit the inflammatory activation of human endothelial cells, although the exact mechanism through which GILZ affects NF-kB p65 DNA binding remains unclear [87]. 


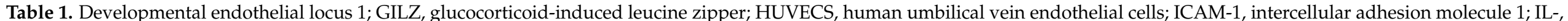

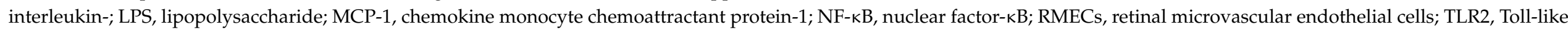
receptor 2; TNF- $\alpha$, tumor necrosis factor $\alpha$; Tregs, regulatory T cells.

\begin{tabular}{|c|c|c|c|}
\hline In Vitro/In Vivo Model & Treatment & Results & Reference \\
\hline HUVECs(GILZ overexpression) & TNF- $\alpha$ & Reduction of IL-6, IL-8, E-selectin, ICAM-1, MCP-1 & [87] \\
\hline HUVECs(GILZ silencing) & TNF- $\alpha$ & No effect & [87] \\
\hline RMECs(GILZ overexpression) & LPS & $\begin{array}{l}\text { Inhibition of NF- } k \text { B nuclear translocation; reduction } \\
\text { of ICAM-1, MCP-1 }\end{array}$ & [89] \\
\hline Mouse salivary gland cells & IL-23 & $\begin{array}{l}\text { Inhibition of GILZ; elevation of IL-17; reduction of } \\
\text { Del-1 }\end{array}$ & {$[90]$} \\
\hline $\begin{array}{l}\text { Primary rat cardiomyocytes, } \\
\text { H9c2 cells }\end{array}$ & Dexamethasone & Elevation of GILZ & [91] \\
\hline C57BL/6 mice & Dexamethasone & Elevation of myocardial GILZ & [91] \\
\hline H9c2 cells(GILZ overexpression) & Doxorubicin & Decreased apoptosis & [92] \\
\hline H9c2 cells(GILZ silencing) & Doxorubicin & Increased apoptosis & [92] \\
\hline GILZ-knockout mice & Angiotensin II infusion & $\begin{array}{l}\text { Increased cardiomyocyte hypertrophy, } \\
\text { diastolic dysfunction }\end{array}$ & [94] \\
\hline
\end{tabular}


A second study investigated the role of GILZ in human healthy saphenous veins and degenerated aortocoronary saphenous vein bypass grafts obtained from patients undergoing coronary bypass surgery. A significant reduction of GILZ mRNA and protein expression in degenerated aortocoronary saphenous veins was accompanied by a marked increase in inflammatory markers Toll-like receptor 2 (TLR2) and MCP-1. In addition, endogenous GILZ function was assessed in HUVECs. Under pro-inflammatory condition (TNF- $\alpha$ treatment), both GILZ mRNA and protein levels were downregulated whereas TLR2 and MCP-1 were upregulated; contrarily, laminar shear stress (in an anti-inflammatory and anti-atherosclerotic setting) induced GILZ mRNA and protein elevation. Mechanistically, modulation of GILZ expression in HUVECs involved p38 mitogen-activated protein kinase and ZFP36 (known to destabilize GILZ mRNA in macrophages). Finally, to determine functional implications of GILZ downregulation, GILZ gene was silenced by siRNA and the NF- $\kappa$ B activation pathway was assessed. In GILZ knockdown HUVECs, NF- $\mathrm{B}$ activation and p65/p50 subunit nuclear translocation were increased when compared to control transfected cells. Moreover, TNF- $\alpha$ promoted upregulation of TLR2, ICAM-1 and E-selectin in HUVECs lacking GILZ. These data showed that the absence of GILZ drives a pro-inflammatory response and that its modulation might be a critical step in vascular adverse remodeling and atherogenesis [88].

An additional mechanism regarding GILZ-induced NF- $\kappa$ B inhibition was determined in rat primary retinal microvascular endothelial cells using lentivirus-mediated GILZ overexpression or silencing. In pathological conditions, these cells secrete pro-inflammatory cytokines, which promote leukocyte adhesion, undermine the retinal vascular barrier integrity, and ultimately lead to inflammatory retinopathy and neuronal damage. The study established that GILZ overexpression inhibited NF- $\kappa B$ p65 nuclear translocation in retinal microvascular endothelial cells with lipopolysaccharide stimulation. Interestingly, NF- $\mathrm{kB}$ signaling shutdown did not involve the degradation of inhibitory $\kappa \mathrm{B}$ but was associated with enhanced p65 dephosphorylation (at Ser536) that, in turn, is responsible for the downregulated ICAM-1 and MCP-1 expression. In contrast, GILZ silencing resulted in significant increases in ICAM-1 and MCP-1 expression after lipopolysaccharide. The regulatory effects of GILZ on retinal microvascular endothelial cells were confirmed by analysis of retinal inflammation in vivo. Intravitreal injection of lipopolysaccharide decreased retinal GILZ and increased at the same time ICAM-1 and MCP-1 expression; contrarily, in GILZ-overexpressing retinas, these increases were markedly attenuated [89].

Another demonstration of GILZ involvement in the modulation of vascular inflammation is shown in a study conducted in patients with Sjögren's syndrome, a systemic autoimmune disease of salivary and lacrimal glands, as well as salivary glands of nonobese diabetic mice (a model of Sjögren's syndrome-like disease). First, a marked difference in leukocyte infiltration was observed in the salivary glands of non-obese diabetic mice, compared to control mice, and in biopsy samples of subjects with a diagnosis of Sjögren's syndrome compared to healthy subjects. Second, immunofluorescent images showed a reduced expression of GILZ in both non-obese diabetic mice and Sjögren's syndrome patients with respect to their respective controls. The reduced expression of GILZ was associated with a significant increase in the pro-inflammatory cytokine level, IL-17, and a decrease in developmental endothelial locus 1 (Del-1) expression that serves as an endogenous negative regulator of leukocyte adhesion and transmigration into inflamed tissues. Finally, in vitro IL-23 treatment of mouse salivary gland cells induced a significant reduction in Del1-positive cells along with a marked increase in IL-17-positive cells. Interestingly, co-culture with GILZ-expressing mesenchymal stem cells significantly reversed the pro-inflammatory phenotype of salivary gland cells, abrogating the impact of treatment with IL-23 [90].

Taken together, these findings raise the possibility that induction of endothelial GILZ expression could represent a potential goal for the treatment of the inflamed endothelium. Increasing knowledge of the anti-inflammatory action of GILZ in endothelial cells lays out the new mechanistic background for the targeting of pathological leukocyte recruitment, 
and ideally, may not only attenuate micro- and macrovascular dysfunction but also interfere with the initial step of several chronic pathologies.

\subsection{Myocardial Damage and Remodeling}

In 2013, the first study described the ability of GCs to induce GILZ expression in the myocardium and cardiac cells (primary cultured rat cardiomyocytes and H9c2 cell line). C57BL/ 6 mice were administered intra-peritoneally with dexamethasone or vehicle to address GILZ induction in the myocardium. Mice treated with dexamethasone showed elevated levels of GILZ protein compared to the control group. At the cellular level, GILZ upregulation after GC challenge occurred in both primary rat cardiomyocytes and H9c2 cells with a similar dose- and time-dependent pattern. The blockade of the GR resulted in the absence of GILZ induction after dexamethasone, suggesting the necessity of GR activation for the modulation of GILZ. The evaluation of signaling involved in GC-dependent GILZ induction revealed the role of PKA and p38 MAPK pathways that negatively regulated GILZ expression, as shown by the increase of GILZ expression after exposing cardiomyocytes to p38 or PKA inhibitors [91].

Further insight into the role of GILZ in the heart emerges from the data showing that GILZ mediates GC-dependent cytoprotection. H9c2 cells pre-treated with corticosterone were protected from doxorubicin-induced apoptosis. siRNA-mediated knockdown of GILZ reversed the beneficial effect of corticosterone on doxorubicin-dependent caspase activation. Conversely, GILZ overexpression significantly reduced the number of apoptotic cells and increased cell survival. These findings implied that GILZ is essential for GC-mediated protection. The underlying mechanism of cytoprotection entailed the elevation of Bcl-xL, a pro-survival Bcl2 family member. The overexpression of Bcl-xL protein in the absence of Bcl-xL mRNA modulation likely involves a post-transcriptional mechanism. The physical interaction of Bcl-xL and GILZ, as reported for other proteins (NF- $k \mathrm{~B}, \mathrm{Raf}, \mathrm{Ras}$ ) remains to be determined [92].

The possible involvement of GILZ in the regulation of cell death machinery emerges from acute cryoinjury experiments demonstrating a marked reduction in cardiac GILZ three hours after damage induction. This study also showed that GILZ-overexpressing mesenchymal stem cells injected into the damaged area immediately after cryoinjury have a higher potential to increase in regulatory T cells and IL-10-positive cells, and decrease Th-17 cells, apoptotic and necrotic cells [93].

The most recent study addressing the role of GILZ in cardiac pathophysiology was conducted in GILZ-knockout mice undergoing angiotensin II-releasing pump implantation to induce cardiac hypertrophy and diastolic dysfunction. Firstly, in wild-type animals, chronic infusion of angiotensin II resulted in the upregulation of myocardial GILZ mRNA and protein, strengthening the potential significance of GILZ in cardiovascular pathologies. Unexpectedly, several aspects of angiotensin II-mediated detrimental effects were similar in wild-type and GILZ-knockout mice. The fibrotic response to angiotensin II was similar in both groups suggesting the lack of a significant involvement of GILZ in the development of myocardial fibrosis upon chronic angiotensin II excess. Similarly, the upregulation of inflammatory genes in the heart after angiotensin II infusion was not aggravated by GILZ ablation. Despite these similarities, following angiotensin II infusion, GILZ-knockout mice had a significantly more profound diastolic dysfunction and a thicker left ventricular wall. These facts suggested the presence of cardiomyocyte subcellular changes that might have been responsible for the deficit in ventricular relaxation and myocardial stiffness. Indeed, cardiomyocyte hypertrophy was more severe, and it could explain the enhanced deterioration of diastolic function in GILZ-knockout hearts. Mechanistically, this study suggests that GILZ may interact with FoxP3 and GATA4 in the development of cardiac hypertrophy. FoxP3 and GATA4 were markedly upregulated after Ang II, but in the hearts of GILZ-knockout mice, such an increase was less pronounced (for FoxP3) or absent (for GATA4) [94]. Although the details of molecular interplay of GILZ with FoxP3 or GATA4 in cardiomyocytes remain to be determined, the absence of GILZ may condition their 
expression, leading to the excessive hypertrophic response. This previously unknown role of GILZ in hypertrophic growth can be of great interest from a translational point of view because LV hypertrophy is a risk factor for heart failure and sudden death and represents a valid therapeutic target.

\section{Conclusions}

The relevance of GILZ in cardiovascular biology remains mostly unknown. However, despite the limited availability of studies, it is becoming evident that GILZ participates in several critical processes that, in various scenarios, contribute to alterations in the myocardium and the vascular system (Figure 1). Further research focusing on molecular mechanisms regulated by GILZ in the cardiovascular system is warranted to understand better the pathophysiological background, and conceive new therapeutic opportunities based on targeting GILZ signaling.

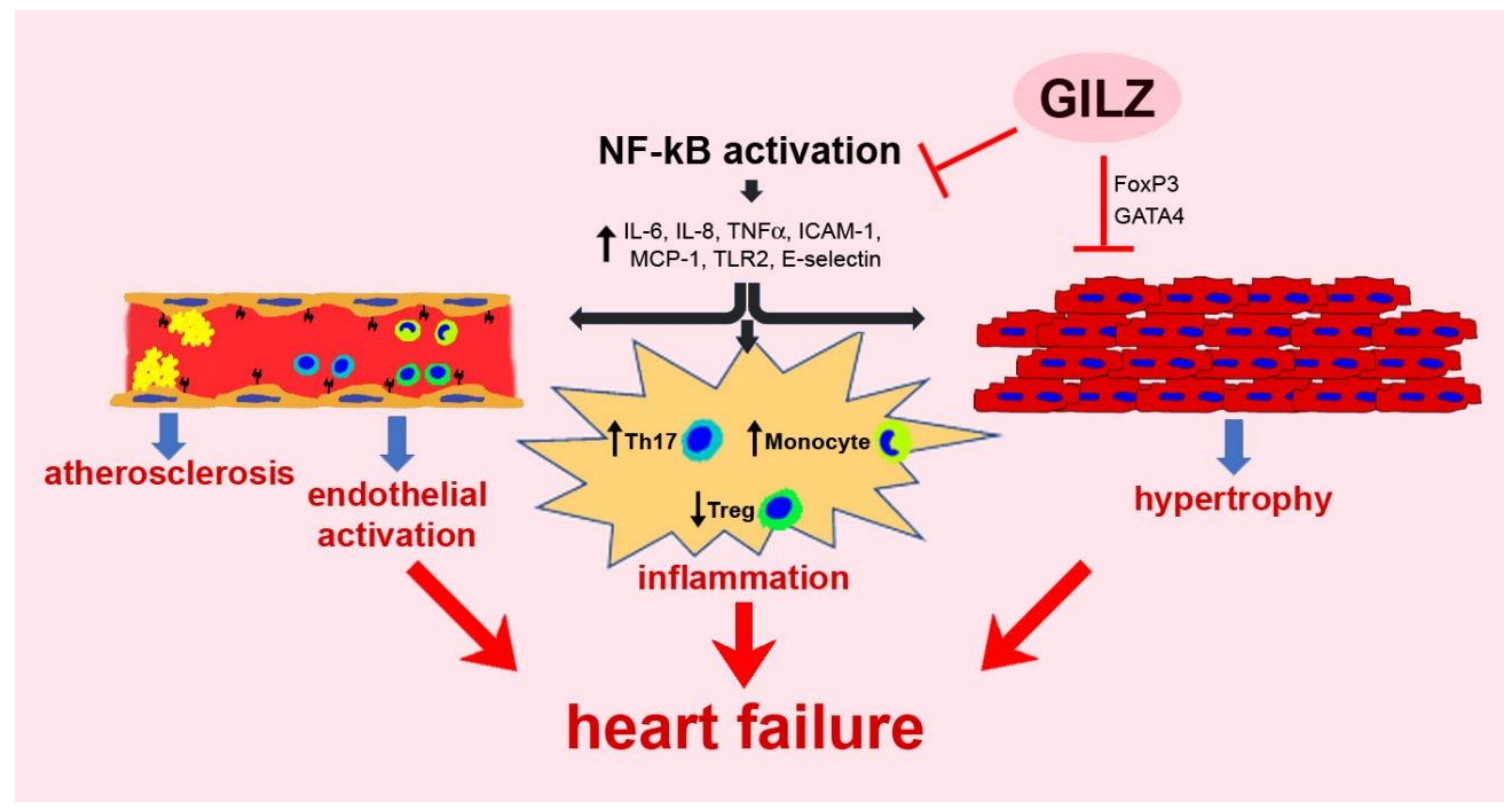

Figure 1. A schematic representation of GILZ participation in pathologic processes regarding the myocardium and the vascular system.

To date, the approaches for the in vivo delivery of GILZ-based molecules (i.e., cellpermeable recombinant GILZ protein) have been tested in pre-clinical studies for a variety of conditions with underlying dysregulation of immune and inflammatory mechanisms, but although promising, such therapies have not entered clinical trials. Furthermore, because of the well-known but yet-to-be addressed harmful effects of prolonged use of GCs, research on GILZ in a cardiovascular context needs to continue.

Author Contributions: Writing-original draft preparation, D.C., K.U. and S.B.; writing-review and editing, O.B., E.C., D.T., L.B. and A.D.A.; supervision, C.R. and F.R.; funding acquisition, L.B., A.D.A. and S.B. All authors have read and agreed to the published version of the manuscript.

Funding: This work was supported by Italian Ministry of Education, University and Research grants [PRIN-2017XZMBYX (A.D.A. and S.B.), PRIN-2017NKB2N4 (L.B.)].

Institutional Review Board Statement: Not applicable.

Informed Consent Statement: Not applicable.

Conflicts of Interest: The authors declare that the research was conducted in the absence of any commercial or financial relationships that could be construed as a potential conflict of interest. 


\section{References}

1. Steptoe, A.; Kivimäki, M. Stress and cardiovascular disease. Nat. Rev. Cardiol. 2021, 9, 360-370. [CrossRef]

2. Selye, H. A syndrome produced by diverse nocuous agents. Nature 1936, 138, 32. [CrossRef]

3. Selye, H.; Fortier, C. Adaptive reactions to stress. Res. Publ. Assoc. Res. Nerv. Ment. Dis. 1949, 29, 3-18. [CrossRef] [PubMed]

4. Mercanoglu, G.; Macit, C.; Mercanoglu, F. Stress as a risk factor for cardiovascular events. Cardiol. Pharmacol. 2015, 4, 2. [CrossRef]

5. $\quad$ van den Beld, A.W.; Kaufman, J.M.; Zillikens, M.C.; Lamberts, S.W.J.; Egan, J.M.; van der Lely, A.J. The physiology of endocrine systems with ageing. Lancet Diabetes Endocrinol. 2018, 6, 647-658. [CrossRef]

6. Timmermans, S.; Souffriau, J.; Libert, C. A General introduction to glucocorticoid biology. Front. Immunol. 2019, 10, 1545. [CrossRef]

7. Walker, B.R. Glucocorticoids and cardiovascular disease. Eur. J. Endocrinol. 2007, 157, 545-559. [CrossRef]

8. Liu, Y.Z.; Wang, Y.X.; Jiang, C.L. Inflammation: The Common Pathway of Stress-Related Diseases. Front. Hum. Neurosci. 2017, 11, 316. [CrossRef]

9. Rog-Zielinska, E.A.; Richardson, R.V.; Denvir, M.A.; Chapman, K.E. Glucocorticoids and foetal heart maturation; implications for prematurity and foetal programming. J. Mol. Endocrinol. 2014, 52, R125-R135. [CrossRef]

10. Walejko, J.M.; Antolic, A.; Koelmel, J.P.; Garrett, T.J.; Edison, A.S.; Keller-Wood, M. Chronic maternal cortisol excess during late gestation leads to metabolic alterations in the newborn heart. Am. J. Physiol. Endocrinol. Metab. 2019, 316, E546-E556. [CrossRef] [PubMed]

11. Liu, B.; Zhang, T.N.; Knight, J.K.; Goodwin, J.E. The Glucocorticoid receptor in cardiovascular health and disease. Cells 2019, 8, 1227. [CrossRef]

12. Ramamoorthy, S.; Cidlowski, J.A. Corticosteroids: Mechanisms of action in health and disease. Rheum. Dis. Clin. North Am. 2016, 42, 15-31. [CrossRef]

13. Tomlinson, J.W.; Walker, E.A.; Bujalska, I.J.; Draper, N.; Lavery, G.G.; Cooper, M.S.; Hewison, M.; Stewart, P.M. 11betahydroxysteroid dehydrogenase type 1: A tissue-specific regulator of glucocorticoid response. Endocr. Rev. 2004, 25, 831-866. [CrossRef]

14. Bereshchenko, O.; Bruscoli, S.; Riccardi, C. Glucocorticoids, Sex Hormones, and Immunity. Front. Immunol. $2018,9,1332$. [CrossRef]

15. Oakley, R.H.; Cidlowski, J.A. The biology of the glucocorticoid receptor: New signaling mechanisms in health and disease. J. Allergy Clin. Immunol. 2013, 132, 1033-1044. [CrossRef]

16. Hardy, R.S.; Raza, K.; Cooper, M.S. Therapeutic glucocorticoids: Mechanisms of actions in rheumatic diseases. Nat. Rev. Rheumatol. 2020, 16, 133-144. [CrossRef]

17. Croxtall, J.D.; Choudhury, Q.; Flower, R.J. Glucocorticoids act within minutes to inhibit recruitment of signalling factors to activated EGF receptors through a receptor-dependent, transcription-independent mechanism. Br. J. Pharmacol. 2000, 130, 289-298. [CrossRef]

18. Kfir-Erenfeld, S.; Sionov, R.V.; Spokoini, R.; Cohen, O.; Yefenof, E. Protein kinase networks regulating glucocorticoid-induced apoptosis of hematopoietic cancer cells: Fundamental aspects and practical considerations. Leuk. Lymphoma 2010, 51, 1968-2005. [CrossRef] [PubMed]

19. Vandevyver, S.; Dejager, L.; Libert, C. Comprehensive overview of the structure and regulation of the glucocorticoid receptor. Endocr. Rev. 2014, 35, 671-693. [CrossRef]

20. Lee, S.R.; Kim, H.K.; Youm, J.B.; Dizon, L.A.; Song, I.S.; Jeong, S.H.; Seo, D.Y.; Ko, K.S.; Rhee, B.D.; Kim, N.; et al. Non-genomic effect of glucocorticoids on cardiovascular system. Pflügers Arch. Eur. J. Physiol. 2012, 464, 549-559. [CrossRef]

21. Song, I.H.; Buttgereit, F. Non-genomic glucocorticoid effects to provide the basis for new drug developments. Mol. Cell. Endocrinol. 2006, 246, 142-146. [CrossRef]

22. Clarck, A.R.; Lasa, M. Crosstalk between glucocorticoids and mitogen-activated protein kinase signalling pathways. Curr. Opin. Pharmacol. 2003, 3, 404-411. [CrossRef]

23. D'Adamio, F.; Zollo, O.; Moraca, R.; Ayroldi, E.; Bruscoli, S.; Bartoli, A.; Cannarile, L.; Migliorati, G.; Riccardi, C. A new dexamethasone-induced gene of the leucine zipper family protects T lymphocytes from TCR/CD3-activated cell death. Immunity 1997, 7, 803-812. [CrossRef]

24. Cannarile, L.; Zollo, O.; D’Adamio, F.; Ayroldi, E.; Marchetti, C.; Tabilio, A.; Bruscoli, S.; Riccardi, C. Cloning, chromosomal assignment and tissue distribution of human GILZ, a glucocorticoid hormone-induced gene. Cell Death Differ. 2001, 8, $201-203$. [CrossRef]

25. Bereshchenko, O.; Migliorati, G.; Bruscoli, S.; Riccardi, C. Glucocorticoid-induced leucine zipper: A novel anti-inflammatory molecule. Front. Pharmacol. 2019, 10, 308. [CrossRef]

26. Mittelstadt, P.R.; Ashwell, J.D. Inhibition of AP-1 by the glucocorticoid-inducible protein GILZ. J. Biol. Chem. 2001, 276, 29603-29610. [CrossRef]

27. Ayroldi, E.; Migliorati, G.; Bruscoli, S.; Marchetti, C.; Zollo, O.; Cannarile, L.; D'Adamio, F.; Riccardi, C. Modulation of T-cell activation by the glucocorticoid-induced leucine zipper factor via inhibition of nuclear factor kappaB. Blood 2001, 98, 743-753. [CrossRef]

28. Ayroldi, E.; Zollo, O.; Macchiarulo, A.; Di Marco, B.; Marchetti, C.; Riccardi, C. Glucocorticoid-induced leucine zipper inhibits the Raf-extracellular signal-regulated kinase pathway by binding to Raf-1. Mol. Cell. Biol. 2002, 22, 7929-7941. [CrossRef] 
29. Ayroldi, E.; Zollo, O.; Bastianelli, A.; Marchetti, C.; Agostini, M.; Di Virgilio, R.; Riccardi, C. GILZ mediates the antiproliferative activity of glucocorticoids by negative regulation of Ras signaling. J. Clin. Investig. 2007, 117, 1605-1615. [CrossRef]

30. Di Marco, B.; Massetti, M.; Bruscoli, S.; Macchiarulo, A.; Di Virgilio, R.; Velardi, E.; Donato, V.; Migliorati, G.; Riccardi, C. Glucocorticoid-induced leucine zipper (GILZ)/NF-kappaB interaction: Role of GILZ homo-dimerization and C-terminal domain. Nucleic Acids Res. 2007, 35, 517-528. [CrossRef] [PubMed]

31. Ricci, E.; Ronchetti, S.; Pericolini, E.; Gabrielli, E.; Cari, L.; Gentili, M.; Roselletti, E.; Migliorati, G.; Vecchiarelli, A.; Riccardi, C. Role of the glucocorticoid-induced leucine zipper gene in dexamethasone-induced inhibition of mouse neutrophil migration via control of annexin A1 expression. FASEB J. 2017, 31, 3054-3065. [CrossRef]

32. Yang, Y.H.; Aeberli, D.; Dacumos, A.; Xue, J.R.; Morand, E.F. Annexin-1 regulates macrophage IL-6 and TNF via glucocorticoidinduced leucine zipper. J. Immunol. 2009, 183, 1435-1445. [CrossRef]

33. Delfino, D.V.; Spinicelli, S.; Pozzesi, N.; Pierangeli, S.; Velardi, E.; Bruscoli, S.; Martelli, M.P.; Pettirossi, V.; Falchi, L.; Kang, T.-B.; et al. Glucocorticoid-induced activation of caspase- 8 protects the glucocorticoid-induced protein Gilz from proteasomal degradation and induces its binding to SUMO-1 in murine thymocytes. Cell Death Differ. 2011, 18, 183-190. [CrossRef] [PubMed]

34. Cohen, N.; Mouly, E.; Hamdi, H.; Maillot, M.C.; Pallardy, M.; Godot, V.; Capel, F.; Balian, A.; Naveau, S.; Galanaud, P.; et al. GILZ expression in human dendritic cells redirects their maturation and prevents antigen-specific T lymphocyte response. Blood 2006, 107, 2037-2044. [CrossRef] [PubMed]

35. Bruscoli, S.; Biagioli, M.; Sorcini, D.; Frammartino, T.; Cimino, M.; Sportoletti, P.; Mazzon, E.; Bereshchenko, O.; Riccardi, C. Lack of glucocorticoid-induced leucine zipper (GILZ) deregulates B-cell survival and results in B-cell lymphocytosis in mice. Blood 2015, 126, 1790-1801. [CrossRef] [PubMed]

36. Bruscoli, S.; Sorcini, D.; Flamini, S.; Gagliardi, A.; Adamo, F.; Ronchetti, S.; Migliorati, G.; Bereshchenko, O.; Riccardi, C. Glucocorticoid-induced leucine zipper inhibits interferon-gamma production in B cells and suppresses colitis in mice. Front. Immunol. 2018, 9, 1720. [CrossRef]

37. Vago, J.P.; Tavares, L.P.; Garcia, C.C.; Lima, K.M.; Perucci, L.O.; Vieira, É.L.; Nogueira, C.R.C.; Soriani, F.M.; Martins, J.O.; Silva, P.M.R.; et al. The role and effects of glucocorticoid-induced leucine zipper in the context of inflammation resolution. J. Immunol. 2015, 194, 4940-4950. [CrossRef]

38. Cannarile, L.; Fallarino, F.; Agostini, M.; Cuzzocrea, S.; Mazzon, E.; Vacca, C.; Genovese, T.; Migliorati, G.; Ayroldi, E.; Riccardi, C. Increased GILZ expression in transgenic mice up-regulates Th-2 lymphokines. Blood 2006, 107, 1039-1047. [CrossRef]

39. Cannarile, L.; Cuzzocrea, S.; Santucci, L.; Agostini, M.; Mazzon, E.; Esposito, E.; Muià, C.; Coppo, M.; di Paola, R.; Riccardi, C. Glucocorticoid-induced leucine zipper is protective in Th1-mediated models of colitis. Gastroenterology 2009, 136, 530-541. [CrossRef]

40. Bereshchenko, O.; Coppo, M.; Bruscoli, S.; Biagioli, M.; Cimino, M.; Frammartino, T.; Sorcini, D.; Venanzi, A.; Di Sante, M.; Riccardi, C. GILZ promotes production of peripherally induced Treg cells and mediates the crosstalk between glucocorticoids and TGF- $\beta$ signaling. Cell Rep. 2014, 7, 464-475. [CrossRef]

41. Esposito, E.; Bruscoli, S.; Mazzon, E.; Paterniti, I.; Coppo, M.; Velardi, E.; Cuzzocrea, S.; Riccardi, C. Glucocorticoid-induced leucine zipper (GILZ) over-expression in T lymphocytes inhibits inflammation and tissue damage in spinal cord injury. Neurotherapeutics 2012, 9, 210-225. [CrossRef]

42. Luz-Crawford, P.; Tejedor, G.; Mausset-Bonnefont, A.L.; Beaulieu, E.; Morand, E.F.; Jorgensen, C.; Noël, D.; Djouad, F. Glucocorticoid-induced leucine zipper governs the therapeutic potential of mesenchymal stem cells by inducing a switch from pathogenic to regulatory Th17 cells in a mouse model of collagen-induced arthritis. Arthritis Rheumatol. 2015, 67, 1514-1524. [CrossRef]

43. Crisafulli, C.; Bruscoli, S.; Esposito, E.; Mazzon, E.; Di Paola, R.; Genovese, T.; Bramanti, P.; Migliorati, G.; Cuzzocrea, S. PPARalpha contributes to the anti- inflammatory activity of 17beta-estradiol. J. Pharmacol. Exp. Ther. 2009, 331, 796-807. [CrossRef] [PubMed]

44. Rinaldi, B.; Pieri, L.; Donniacuo, M.; Cappetta, D.; Capuano, A.; Domenici, L.; Carnuccio, R.; Romagnoli, P.; Filippelli, A.; Rossi, F. Rosiglitazone reduces the inflammatory response in a model of vascular injury in rats. Shock 2009, 32, 638-644. [CrossRef]

45. Cuzzocrea, S.; Bruscoli, S.; Mazzon, E.; Crisafulli, C.; Donato, V.; Di Paola, R.; Velardi, E.; Esposito, E.; Nocentini, G.; Riccardi, C. Peroxisome proliferator-activated receptor-alpha contributes to the anti-inflammatory activity of glucocorticoids. Mol. Pharmacol. 2008, 73, 323-337. [CrossRef] [PubMed]

46. Robert-Nicoud, M.; Flahaut, M.; Elalouf, J.M.; Nicod, M.; Salinas, M.; Bens, M.; Doucet, A.; Wincker, P.; Artiguenave, F.; Horisberger, J.-D.; et al. Transcriptome of a mouse kidney cortical collecting duct cell line: Effects of aldosterone and vasopressin. Proc. Natl. Acad. Sci. USA 2001, 98, 2712-2716. [CrossRef]

47. Ueda, K.; Fujiki, K.; Shirahige, K.; Gomez-Sanchez, C.E.; Fujita, T.; Nangaku, M.; Nagase, M. Genome-wide analysis of murine renal distal convoluted tubular cells for the target genes of mineralocorticoid receptor. Biochem. Biophys. Res. Commun. 2014, 445, 132-137. [CrossRef]

48. Bhalla, V.; Soundararajan, R.; Pao, A.C.; Li, H.; Pearce, D. Disinhibitory pathways for control of sodium transport: Regulation of ENaC by SGK1 and GILZ. Am. J. Physiol. Renal. Physiol. 2006, 291, F714-F721. [CrossRef]

49. Cari, L.; Ricci, E.; Gentili, M.; Petrillo, M.G.; Ayroldi, E.; Ronchetti, S.; Nocentini, G.; Riccardi, C. A focused Real Time PCR strategy to determine GILZ expression in mouse tissues. Results Immunol. 2015, 5, 37-42. [CrossRef] [PubMed] 
50. Bruscoli, S.; Donato, V.; Velardi, E.; Di Sante, M.; Migliorati, G.; Donato, R.; Riccardi, C. Glucocorticoid-induced leucine zipper (GILZ) and long GILZ inhibit myogenic differentiation and mediate anti-myogenic effects of glucocorticoids. J. Biol. Chem. 2010, 285, 10385-10396. [CrossRef]

51. Ayyar, V.S.; Almon, R.R.; Jusko, W.J.; DuBois, D.C. Quantitative tissue-specific dynamics of in vivo GILZ mRNA expression and regulation by endogenous and exogenous glucocorticoids. Physiol. Rep. 2015, 3, e12382. [CrossRef]

52. Venanzi, A.; Di Sante, M.; Bruscoli, S.; Biagioli, M.; Sorcini, D.; Cimino, M.; Frammartino, T.; Bereshchenko, O.; Franconi, F.; Riccardi, C. Recombinant long-glucocorticoid-induced leucine zipper (L-GILZ) protein restores the control of proliferation in gilz KO spermatogonia. Eur. J. Pharm. Sci. 2014, 63, 22-28. [CrossRef]

53. Fowden, A.L.; Li, J.; Forhead, A.J. Glucocorticoids and the preparation for life after birth: Are there long-term consequences of the life insurance? Proc. Nutr. Soc. 1998, 57, 113-122. [CrossRef]

54. Roberts, D.; Brown, J.; Medley, N.; Dalziel, S.R. Antenatal corticosteroids for accelerating fetal lung maturation for women at risk of preterm birth. Cochrane Database Syst. Rev. 2017, 3, CD004454. [CrossRef]

55. Mulder, E.J.; de Heus, R.; Visser, G.H. Antenatal corticosteroid therapy: Short-term effects on fetal behaviour and haemodynamics. Semin. Fetal Neonatal Med. 2009, 14, 151-156. [CrossRef]

56. Giraud, G.D.; Louey, S.; Jonker, S.; Schultz, J.; Thornburg, K.L. Cortisol stimulates cell cycle activity in the cardiomyocyte of the sheep fetus. Endocrinology 2006, 147, 3643-3649. [CrossRef]

57. Rog-Zielinska, E.A.; Thomson, A.; Kenyon, C.J.; Brownstein, D.G.; Moran, C.M.; Szumska, D.; Michailidou, Z.; Richardson, J.; Owen, E.; Watt, A.; et al. Glucocorticoid receptor is required for foetal heart maturation. Hum. Mol. Genet. 2013, 22, 3269-3282. [CrossRef] [PubMed]

58. Oakley, R.H.; Ren, R.; Cruz-Topete, D.; Bird, G.S.; Myers, P.H.; Boyle, M.C.; Schneider, M.D.; Willis, M.; Cidlowski, J.A. Essential role of stress hormone signaling in cardiomyocytes for the prevention of heart disease. Proc. Natl. Acad. Sci. USA 2013, 110, 17035-17040. [CrossRef]

59. Rog-Zielinska, E.A.; Craig, M.A.; Manning, J.R.; Richardson, R.V.; Gowans, G.J.; Dunbar, D.R.; Gharbi, K.; Kenyon, C.J.; Holmes, M.C.; Hardie, D.G.; et al. Glucocorticoids promote structural and functional maturation of foetal cardiomyocytes: A role for PGC-1 $\alpha$. Cell Death Differ. 2015, 22, 1106-1116. [CrossRef] [PubMed]

60. van Rossum, E.F.; Koper, J.W.; Huizenga, N.A.; Uitterlinden, A.G.; Janssen, J.A.; Brinkmann, A.O.; Grobbee, D.E.; de Jong, F.H.; van Duyn, C.M.; Pols, H.A.; et al. A polymorphism in the glucocorticoid receptor gene, which decreases sensitivity to glucocorticoids in vivo, is associated with low insulin and cholesterol levels. Diabetes 2002, 51, 3128-3134. [CrossRef] [PubMed]

61. Roussel, R.; Reis, A.F.; Dubois-Laforgue, D.; Bellanné-Chantelot, C.; Timsit, J.; Velho, G. The N363S polymorphism in the glucocorticoid receptor gene is associated with overweight in subjects with type 2 diabetes mellitus. Clin. Endocrinol. 2003, 59, 237-241. [CrossRef]

62. Lin, R.C.; Wang, X.L.; Morris, B.J. Association of coronary artery disease with glucocorticoid receptor N363S variant. Hypertension 2003, 41, 404-407. [CrossRef]

63. Rosmond, R.; Chagnon, Y.C.; Holm, G.; Chagnon, M.; Pérusse, L.; Lindell, K.; Carlsson, B.; Bouchard, C.; Björntorp, P.A. A glucocorticoid receptor gene marker is associated with abdominal obesity, leptin, and dysregulation of the hypothalamic-pituitaryadrenal axis. Obes. Res. 2000, 8, 211-218. [CrossRef]

64. Güder, G.; Bauersachs, J.; Frantz, S.; Weismann, D.; Allolio, B.; Ertl, G.; Angermann, C.E.; Störk, S. Complementary and incremental mortality risk prediction by cortisol and aldosterone in chronic heart failure. Circulation 2007, 115, 1754-1761. [CrossRef]

65. Ren, R.; Oakley, R.H.; Cruz-Topete, D.; Cidlowski, J.A. Dual role for glucocorticoids in cardiomyocyte hypertrophy and apoptosis. Endocrinology 2012, 153, 5346-5360. [CrossRef] [PubMed]

66. Severinova, E.; Alikunju, S.; Deng, W.; Dhawan, P.; Sayed, N.; Sayed, D. Glucocorticoid receptor-binding and transcriptome signature in cardiomyocytes. J. Am. Heart Assoc. 2019, 8, e011484. [CrossRef]

67. Ungvari, Z.; Tarantini, S.; Donato, A.J.; Galvan, V.; Csiszar, A. Mechanisms of vascular aging. Circ. Res. 2018, $123,849-867$. [CrossRef]

68. Ong, S.L.; Whitworth, J.A. Glucocorticoid-induced hypertension and the nitric oxide system. Expert Rev. Endocrinol. Metab. 2012, 7, 273-280. [CrossRef]

69. Nauck, M.; Karakiulakis, G.; Perruchoud, A.P.; Papakonstantinou, E.; Roth, M. Corticosteroids inhibit the expression of the vascular endothelial growth factor gene in human vascular smooth muscle cells. Eur. J. Pharmacol. 1998, 341, 309-315. [CrossRef]

70. Oliver, A.; Ciulla, T.A. Corticosteroids as antiangiogenic agents. Ophthalmol. Clin. North Am. 2006, 19, 345-351. [CrossRef]

71. Seidel, T.; Fiegle, D.J.; Baur, T.J.; Ritzer, A.; Nay, S.; Heim, C.; Weyand, M.; Milting, H.; Oakley, R.H.; Cidlowski, J.; et al. Glucocorticoids preserve the t-tubular system in ventricular cardiomyocytes by upregulation of autophagic flux. Basic Res. Cardiol. 2019, 114, 47. [CrossRef]

72. Parikh, S.S.; Blackwell, D.J.; Gomez-Hurtado, N.; Frisk, M.; Wang, L.; Kim, K.; Dahl, C.P.; Fiane, A.; Tønnessen, T.; Kryshtal, D.O.; et al. Thyroid and glucocorticoid hormones promote functional T-tubule development in human-induced pluripotent stem cell-derived cardiomyocytes. Circ. Res. 2017, 121, 1323-1330. [CrossRef] [PubMed]

73. Shirazi, L.F.; Bissett, J.; Romeo, F.; Mehta, J.L. Role of inflammation in heart failure. Curr. Atheroscler. Rep. 2017, 19, 27. [CrossRef]

74. Torre-Amione, G.; Kapadia, S.; Lee, J.; Durand, J.B.; Bies, R.D.; Young, J.B.; Mann, D.L. Tumor necrosis factor-alpha and tumor necrosis factor receptors in the failing human heart. Circulation 1996, 93, 704-711. [CrossRef] 
75. Bartekova, M.; Radosinska, J.; Jelemensky, M.; Dhalla, N.S. Role of cytokines and inflammation in heart function during health and disease. Heart Fail. Rev. 2018, 23, 733-758. [CrossRef]

76. Deanfield, J.E.; Halcox, J.P.; Rabelink, T.J. Endothelial function and dysfunction: Testing and clinical relevance. Circulation 2007, 115, 1285-1295. [CrossRef]

77. Bajpai, G.; Schneider, C.; Wong, N.; Bredemeyer, A.; Hulsmans, M.; Nahrendorf, M.; Epelman, S.; Kreisel, D.; Liu, Y.; Itoh, A.; et al. The human heart contains distinct macrophage subsets with divergent origins and functions. Nat. Med. 2018, 24, 1234-1245. [CrossRef]

78. Sager, H.B.; Hulsmans, M.; Lavine, K.J.; Moreira, M.B.; Heidt, T.; Courties, G.; Sun, Y.; Iwamoto, Y.; Tricot, B.; Khan, O.F.; et al. Proliferation and recruitment contribute to myocardial macrophage expansion in chronic heart failure. Circ. Res. 2016, 119, 853-864. [CrossRef]

79. Lavine, K.J.; Pinto, A.R.; Epelman, S.; Kopecky, B.J.; Clemente-Casares, X.; Godwin, J.; Rosenthal, N.; Kovacic, J.C. The macrophage in cardiac homeostasis and disease: JACC macrophage in CVD series (Part 4). J. Am. Coll. Cardiol. 2018, 72, 2213-2230. [CrossRef]

80. Hoppstädter, J.; Kessler, S.M.; Bruscoli, S.; Huwer, H.; Riccardi, C.; Kiemer, A.K. Glucocorticoid-induced leucine zipper: A critical factor in macrophage endotoxin tolerance. J. Immunol. 2015, 194, 6057-6067. [CrossRef]

81. Kaptoge, S.; Seshasai, S.R.; Gao, P.; Freitag, D.F.; Butterworth, A.S.; Borglykke, A.; Di Angelantonio, E.; Gudnason, V.; Rumley, A.; Lowe, G.D.; et al. Inflammatory cytokines and risk of coronary heart disease: New prospective study and updated meta-analysis. Eur. Heart J. 2014, 35, 578-589. [CrossRef]

82. Ley, K.; Laudanna, C.; Cybulsky, M.I.; Nourshargh, S. Getting to the site of inflammation: The leukocyte adhesion cascade updated. Nat. Rev. Immunol. 2007, 7, 678-689. [CrossRef]

83. Daiber, A.; Xia, N.; Steven, S.; Oelze, M.; Hanf, A.; Kröller-Schön, S.; Münzel, T.; Li, H. New therapeutic implications of endothelial nitric oxide synthase (eNOS) function/dysfunction in cardiovascular disease. Int. J. Mol. Sci. 2019, 20, 187. [CrossRef]

84. Zuchi, C.; Tritto, I.; Carluccio, E.; Mattei, C.; Cattadori, G.; Ambrosio, G. Role of endothelial dysfunction in heart failure. Heart Fail. Rev. 2020, 25, 21-30. [CrossRef] [PubMed]

85. Galkina, E.; Ley, K. Immune and inflammatory mechanisms of atherosclerosis. Annu Rev. Immunol. 2009, 27, 165-197. [CrossRef]

86. McCormick, S.M.; Eskin, S.G.; McIntire, L.V.; Teng, C.L.; Lu, C.M.; Russell, C.G.; Chittur, K.K. DNA microarray reveals changes in gene expression of shear stressed human umbilical vein endothelial cells. Proc. Natl. Acad. Sci. USA 2001, 98, 8955-8960. [CrossRef]

87. Cheng, Q.; Fan, H.; Ngo, D.; Beaulieu, E.; Leung, P.; Lo, C.Y.; Burgess, R.; Van Der Zwan, Y.G.; White, S.J.; Khachigian, L.M.; et al. GILZ overexpression inhibits endothelial cell adhesive function through regulation of NF- $\mathrm{B}$ and MAPK activity. J. Immunol. 2013, 191, 424-433. [CrossRef]

88. Hahn, R.T.; Hoppstädter, J.; Hirschfelder, K.; Hachenthal, N.; Diesel, B.; Kessler, S.M.; Huwer, H.; Kiemer, A.K. Downregulation of the glucocorticoid-induced leucine zipper (GILZ) promotes vascular inflammation. Atherosclerosis 2014, 234, 391-400. [CrossRef]

89. Gu, R.; Lei, B.; Jiang, C.; Xu, G. Glucocorticoid-induced leucine zipper suppresses ICAM-1 and MCP-1 expression by dephosphorylation of NF-кB p65 in retinal endothelial cells. Investig. Ophthalmol. Vis. Sci. 2017, 58, 631-641. [CrossRef] [PubMed]

90. Qin, X.; Liu, J.Y.; Abdelsayed, R.; Shi, X.; Yu, J.C.; Mozaffari, M.S.; Baban, B. The status of glucocorticoid-induced leucine zipper protein in the salivary glands in Sjögren's syndrome: Predictive and prognostic potentials. EPMA J. 2016, 7, 3. [CrossRef] [PubMed]

91. Aguilar, D.C.; Strom, J.; Xu, B.; Kappeler, K.; Chen, Q.M. Expression of glucocorticoid-induced leucine zipper (GILZ) in cardiomyocytes. Cardiovasc. Toxicol. 2013, 13, 91-99. [CrossRef] [PubMed]

92. Aguilar, D.; Strom, J.; Chen, Q.M. Glucocorticoid induced leucine zipper inhibits apoptosis of cardiomyocytes by doxorubicin. Toxicol. Appl. Pharmacol. 2014, 276, 55-62. [CrossRef] [PubMed]

93. Baban, B.; Yin, L.; Qin, X.; Liu, J.Y.; Shi, X.; Mozaffari, M.S. The role of GILZ in modulation of adaptive immunity in a murine model of myocardial infarction. Exp. Mol. Pathol. 2017, 102, 408-414. [CrossRef] [PubMed]

94. Cappetta, D.; De Angelis, A.; Flamini, S.; Cozzolino, A.; Bereshchenko, O.; Ronchetti, S.; Cianflone, E.; Gagliardi, A.; Ricci, E.; Rafaniello, C.; et al. Deficit of glucocorticoid-induced leucine zipper amplifies angiotensin-induced cardiomyocyte hypertrophy and diastolic dysfunction. J. Cell. Mol. Med. 2021, 25, 217-228. [CrossRef] [PubMed] 